\title{
Nutritional value and growth performance of sea worms (Nereis sp.) fed with Hermetia illucens maggot flour and grated coconut (Cocos nucifera) as natural feed
}

\author{
VIVI ENDAR HERAWATI ${ }^{1, \vartheta}$, PINANDOYO ${ }^{1}$, SETO WINDARTO $^{1}$, NURMANITA RISMANINGSIH ${ }^{2}$, \\ PUTUT HAR RIYADI ${ }^{3}$, Y.S. DARMANTO ${ }^{3}$, OCKY KARNA RADJASA ${ }^{4}$ \\ ${ }^{1}$ Department of Aquaculture, Faculty of Fisheries and Marine Sciences, Universitas Diponegoro. J1. Prof. H. Soedarto S.H., Semarang 50275, Central \\ Java, Indonesia. Tel: +62-24-7474698, Fax.: +62-24-7474698, `email: viviendar23@ gmail.com \\ ${ }^{2}$ Department of Materials Chemistry, Graduate School of Engineering, Nagoya University. Furo-cho, Chikusa-ku, Nagoya 464-8603, Japan \\ ${ }^{3}$ Department of Fishery Product Technology, Faculty of Fisheries and Marine Sciences, Universitas Diponegoro. Jl. Prof. H. Soedarto S.H., Semarang \\ 50275, Central Java, Indonesia \\ ${ }^{4}$ Department of Marine Science, Faculty of Fisheries and Marine Sciences, Universitas Diponegoro. J1. Prof. H. Soedarto S.H., Semarang 50275, Central \\ Java, Indonesia
}

Manuscript received: 30 August 2020. Revision accepted: 27 October 2020.

\begin{abstract}
Herawati VE, Pinandoyo, Windarto S, Rismaningsih N, Riyadi PH, Darmanto YS, Radjasa OK. 2020. Nutritional value and growth performance of sea worms (Nereis $s p$.) fed with Hermetia illucens maggot flour and grated coconut (Cocos nucifera) as natural feed. Biodiversitas 21: 5431-5437. Sea worms are one of the natural feeds used for shrimp aquaculture. This study aimed to investigate the growth performance and nutritional quality of sea worms (Nereis sp.) fed with Hermetia illucens maggot flour and grated coconut (Cocos nucifera). Nereis sp. individuals were cultured at a density of 100/plastic container for 35 days, and fed twice daily with a feeding rate of $5 \%$ of the total body weight. This study used five treatments, i.e.: A. 50\% maggot flour and 50\% coconut grated, B. $75 \%$ maggot flour and 25\% coconut grated, C. $25 \%$ maggot flour and $75 \%$ grated coconut, D. 100\% maggot flour, and E. $100 \%$ coconut grated. The results showed that the sea worms fed on maggot flour and grated coconut had a significant effect $(P<0.01)$ on the survival rate (SR), feed conversion rate (FCR), and feed efficiency. Treatment D showed the highest absolute growth value, specific growth rate (SGR), feed efficiency, and SR $(0.45 \mathrm{~g}, 3.25 \%, 49.23 \%$, and $99.67 \%)$. Feeding rate $n$ ranged from $30.50 \%$ to $34.67 \%$, and the FCR value ranged from $2.07-2.43 \%$. The highest nutrient contents were observed in treatment $\mathrm{D}$, with $54.05 \%$ protein, $22.54 \%$ fatty acid, $55.46 \mathrm{ppm}$ methionine, and $10.98 \%$ EPA. This result suggested that Nereis sp. fed with $100 \%$ maggot flour had the greatest nutritional quality and growth performance.
\end{abstract}

Keywords: Feed, growth, maggot, Nereis, nutrient

\section{INTRODUCTION}

Sea worms (Nereis sp.) are marine animals that usually live on the coast of tidal areas by digging into the substrate, whether it is sandy, muddy, or sandy loam. Nereis sp. has the potential to be developed for aquaculture (Mouneyrac 2010; Munairi 2012; Gamis et al. 2016; Asnawi 2018). The problem that arises is the availability of Nereis sp.; stocking for farming is still very dependent on catching marine worms in nature, which can cause a decrease in the population of marine worms. Therefore, it is necessary to cultivate marine worms that have the potential to be a source of natural feed. Nereis sp. has the potential to be developed into natural feed for both tiger and whiteleg shrimp. Nereis sp. is used as a shrimp feed because of its nutritional content, which can improve the quality of gamete cells and viability of shrimp larvae (Wibowo et al. 2019). Protein levels of $35-45 \%$, fat levels of $10 \%$, and several types of reproductive hormones are required in shrimp feed. The nutritional content of sea worms is quite high: the average protein content is $>50 \%$, and the average fat content is <15\% (Hadiyanto 2013). Sea worms are deposit feeders that live in the substrate, and emerge in search of food (Munairi 2012). During this time, meeting the quantity of sea worms required for feed still relies on taking animals from their natural habitat (Wibowo et al. 2019). This results in a break in the food chain and a decline in the population of sea worms. The factors that determine the success of cultivation depend on the quality of the feed provided (Gamis et al. 2016)

Two types of feed with high nutritional contents are maggot and grated coconut (Cocos nucifera). Maggot is a source of high animal protein; it contains $30-45 \%$ protein based on the results of maggot proximate composition studies (Azir et al. 2017; Herawati et al. 2019). Grated coconut is a source of vegetable protein; according to the proximate protein analysis of Gamis et al. (2016), grated coconut comprises $14.31 \%$ protein, $6 \%$ fat, $8.4 \%$ fiber, $0.84 \%$ ash, and $57.38 \%$ water. Previous research related to the effects of using maggots as feed has been carried out in several studies, including those on carp (Herawati et al. 2019) and milkfish (Herawati et al. 2020). Previous research related to the effect of feeding showed that grated coconut meat and shrimp head flour could affect the growth of sea worms (Gamis et al. 2016). This study aimed to determine the nutritional quality and growth performance Nereis sp. fed with Hermetia illucens maggot flour and grated coconut. 


\section{MATERIALS AND METHODS}

\section{Animal test}

Nereis sp. were used in the enlargement phase at two months of age, with an average weight of 0.20-0.22 g. The animals tested were kept at 100 individuals/30 L container with a maintenance time of 35 days.

\section{Feed}

The test feed used was maggot flour. The maggots used were 15 days old during maintenance, and were then dried and ground to a flour. Grated coconut was obtained from the market and dried.

\section{Media}

Media, in the form of a coastal mangrove sand substrate, was previously washed clean using a recirculation system with a substrate height of $10 \mathrm{~cm}$ and water height of $3 \mathrm{~cm}$ (Hermawan et al. 2015). The seawater used comes from reservoirs that have gone through a sterilization stage using $10 \mathrm{ppm}$ chlorine and neutralization with 5 ppm sodium thiosulfate.

\section{Methods}

The laboratory research was conducted at Chemical Laboratory, Center for Brackish Water Cultivation Jepara, and Animal Food Science Laboratory, Faculty of Animal Husbandry and Agriculture, Universitas Diponegoro, Semarang, Indonesia.

The study was conducted experimentally with a completely randomized design, using four treatments and three replicates of each. Treatment A: 50\% maggot flour and $50 \%$ grated coconut; treatment B: $75 \%$ maggot flour and $25 \%$ grated coconut; treatment $\mathrm{C}$ : $25 \%$ maggot flour and $75 \%$ grated coconut; treatment D: $100 \%$ maggot flour; and treatment E: $100 \%$ grated coconut. The feed was provided in the morning and evening. The feed was given at a fixed feed rate of 5\% of the biomass (Hartanti and Suyono 2015). Feeding was performed by reducing the water level to about $1 \mathrm{~cm}$ from the substrate surface.

Proximate analysis of the protein content of maggot meal and grated coconut was $52.79 \%$ and $15.26 \%$. Maggot meal has $22.53 \%$ higher protein content for the fat content, which was $30.26 \%$ for and $25.14 \%$ for grated coconut (Table 1). Fatty acid profile of maggot meal and grated coconut as feed on the post-larvae shrimp presented in Table 2.

The highest fatty acid profile analysis of maggot meal was in Linoleic fatty acids, which was $6.83 \%$, while the highest fatty acid profile for grated coconut was in EPA fatty acids, which was $9.13 \%$. The amino acid profile of maggot meal and grated coconut as feed for Nereis sp. was presented in Table 3. The highest amino acid profile of maggot meal was lysine of $48.57 \mathrm{ppm}$, and grated coconut was valine $28.87 \mathrm{ppm}$.

\section{Absolute growth $\left(W_{m}\right)$}

Absolute growth $\left(\mathrm{W}_{\mathrm{m}}\right)$, known based on the average biomass of sea worms (Nereis sp.) calculated using the following formula (Tacon 1993).
Table 1. Proximate analysis of maggot meal and grated coconut as feed (in \%, dry weight)

\begin{tabular}{lcc}
\hline \multirow{2}{*}{ Contents (\%) } & \multicolumn{2}{c}{ Natural feed } \\
\cline { 2 - 3 } & Maggot meal & Grated coconut \\
\hline Protein & 52.79 & 30.26 \\
Fat & 15.26 & 25.14 \\
Ash & 11.25 & 15.20 \\
Crude fiber & 10.63 & 18.93 \\
Nitrogen-free extract & 10.07 & 10.47 \\
Total & 100.00 & 100.00 \\
\hline
\end{tabular}

Table 2. Fatty acid profile of maggot meal and grated coconut

\begin{tabular}{lcc}
\hline Fatty acids profile $(\%)$ & Maggot meal & Grated coconut \\
\hline Myristic & $1.92 \pm 0.05$ & $0.48 \pm 0.09$ \\
Pentadecanoic & $1.09 \pm 0.06$ & $1.15 \pm 0.08$ \\
Palmitic & $4.14 \pm 0.09$ & $4.59 \pm 0.04$ \\
Stearic & $2.51 \pm 0.07$ & $2.91 \pm 0.09$ \\
Oleic/ $\omega 9$ & $3.07 \pm 0.02$ & $2.61 \pm 0.01$ \\
Linoleic/ $\omega 6$ & $6.83 \pm 0.09$ & $7.07 \pm 0.02$ \\
Linolenic/ $\omega 3$ & $4.54 \pm 0.05$ & $5.32 \pm 0.01$ \\
Arachidonic & $0.07 \pm 0.02$ & $0.13 \pm 0.08$ \\
DHA & $1.03 \pm 0.05$ & $6.23 \pm 0.03$ \\
EPA & $5.05 \pm 0.02$ & $9.13 \pm 0.08$ \\
\hline
\end{tabular}

Table 3. Amino acids profile of maggot meal and grated coconut as feed for Nereis sp.

\begin{tabular}{lcc}
\hline Amino acids $(\mathbf{p p m})$ & Maggot meal & Grated coconut \\
\hline Aspartic acid & $38.92 \pm 0.08$ & $23.94 \pm 0.01$ \\
Serine & $15.61 \pm 0.03$ & $17.62 \pm 0.01$ \\
Glutamic acid & $36.61 \pm 0.04$ & $22.37 \pm 0.07$ \\
Glycine & $19.36 \pm 0.04$ & $19.19 \pm 0.01$ \\
Histidine & $9.78 \pm 0.03$ & $19.70 \pm 0.01$ \\
Arginine & $20.51 \pm 0.04$ & $27.28 \pm 0.01$ \\
Threonine & $19.02 \pm 0.09$ & $20.37 \pm 0.01$ \\
Alanine & $40.65 \pm 0.05$ & $22.51 \pm 0.09$ \\
Proline & $20.25 \pm 0.05$ & $19.00 \pm 0.06$ \\
Valine & $30.24 \pm 0.05$ & $28.87 \pm 0.04$ \\
Methionine & $21.10 \pm 0.08$ & $21.40 \pm 0.04$ \\
Lysine & $48.57 \pm 0.04$ & $24.16 \pm 0.01$ \\
Isoleucine & $19.97 \pm 0.03$ & $12.79 \pm 0.04$ \\
Leucine & $32.44 \pm 0.05$ & $26.88 \pm 0.05$ \\
Phenylalanine & $15.49 \pm 0.07$ & $15.98 \pm 0.10$ \\
\hline
\end{tabular}

$$
W_{m}=W_{t}-W_{0}
$$

Where $W_{m}$ is absolute growth average of test animals (g), $W_{t}$ is average weight of test animals at the end of the study $(\mathrm{g})$, and $W_{0}$ is average weight of test animals at the beginning of the study $(\mathrm{g})$.

\section{Specific growth rate (SGR)}

The specific growth rate is calculated by the formula (Tacon 1993) as follows:

$$
\mathrm{SGR}=\frac{\ln W_{t}-\ln W_{0}}{\mathrm{t}} \times 100 \%
$$


Where SGR is specific growth rate $(\%), W_{t}$ is average sea worms' weight at the end of the study $(\mathrm{g})$, and $\mathrm{W}_{0}$ is average sea worms' weight at the beginning of the study (g).

\section{Feed consumption rate}

Feed Consumption Rate is the amount of feed consumed by sea worms, calculated from the total feed given during fish rearing (Tacon 1993).

\section{Efficiency of feed utilization (EFU)}

The efficiency of feed utilization is calculated using the formula (Tacon 1993) as follows:

$$
\mathrm{EFU}=\frac{W_{t}-W_{0}}{\mathrm{~F}} \times 100 \%
$$

Where EFU is Efficiency of Feed Utilization $(\%), W_{t}$ is final biomass at the end of the study $(\mathrm{g}), \mathrm{W}_{0}$ is initial biomass at the beginning of the study $(\mathrm{g})$, and $\mathrm{F}$ is total feed consumed during the study.

\section{Feed conversion ratio (FCR)}

Feed Conversion Ratio (FCR) is the value of the given feed efficiency. Feed conversion ratio using the formula (Tacon, 1993).

$$
\mathrm{FCR}=\frac{\mathrm{F}}{\left(W_{t}+\mathrm{D}\right)-W_{0}}
$$

Where FCR is feed conversion ratio, $\mathrm{F}$ is amount of feed given $(\mathrm{g}), W_{t}$ is weight of fish biomass at time $\mathrm{t}(\mathrm{g})$, $\mathrm{W}_{0}$ is weight of fish biomass at the beginning of maintenance $(\mathrm{g})$, and $\mathrm{D}$ is weight of dead fish biomass during maintenance $(\mathrm{g})$

\section{Survival rate $(S R)$}

The survival rate formula based on Tacon (1993):

$$
\mathrm{SR}=\frac{N_{t}}{N_{0}} \times 100 \%
$$

Where SR is Survival Rate (\%), $N_{t}$ is the number of individuals at the end of the study, and $\mathrm{N}_{0}$ is the number of individuals at the beginning of the study.

\section{Proximate analysis}

The proximate chemical composition of the samples was determined using a standard procedure (Herawati et al 2019). The crude protein content was calculated by multiplying the total nitrogen factor. The difference estimated the carbohydrate content.

\section{The essential amino acid profile}

The amino acid composition of the sample was determined using High-Performance Liquid Chromatography (HPLC) (Shimadzu LC-6A, Japan) (Herawati et al. 2019).

\section{Fatty acid profile}

The fatty acid composition of the sample was determined using a gas chromatograph (Shimadzu, Japan) (Herawati et al. 2019).

\section{Water quality}

The parameters of water quality in sea worm maintenance media for 35 days are presented in Table 4.

Table 4. Water quality parameters of the media for 35 days

\begin{tabular}{lll}
\hline Variable & Range & References \\
\hline DO $(\mathrm{mg} / \mathrm{L})$ & $5.6-6.7$ & $4.20-9.40^{*}$ \\
$\mathrm{pH}$ & $7.6-8.2$ & $7.0-8.5^{* *}$ \\
Temperature $\left({ }^{\circ} \mathrm{C}\right)$ & $28-31$ & $25-31^{* *}$ \\
Salinity & $29-31$ & $5-35^{*}$ \\
\hline Note: $*$ Wibowo et al. $(2019),{ }^{* * H e r m a w a n}$ t & al. $(2019)$
\end{tabular}

Note: *Wibowo et al. (2019), **Hermawan et al. (2019)

\section{Data analysis}

The analyzed data included the absolute growth, feed consumption rate, efficiency of feed utilization (EFU), feed conversion ratio (FCR), specific growth rate (SGR; or daily growth rate), survival rate (SR; or survival), and nutrition of Nereis sp. The results obtained were further descriptively analyzed by statistical tests and presented in graphical form. The data obtained were then analyzed statistically by testing for normality, homogeneity, and additivity. Data that were normal, homogeneous, and additive were then subjected to analysis of variance (ANOVA). ANOVA test results showing real differences were then analyzed using Duncan multiple range test.

\section{RESULTS AND DISCUSSION}

\section{Results}

Based on research that has been done for 35 days, the average value calculation results are presented in Table 5.

Table 5. Average value of absolute growth, SGR, feed consumption rate, EFU, FCR and SR sea worm (Nereis sp.) for 35 maintenance days

\begin{tabular}{llllll}
\hline \multirow{2}{*}{ Variable } & \multicolumn{1}{c}{ Treatments } & \multicolumn{1}{c}{ D } & \multicolumn{1}{c}{ E } \\
\cline { 2 - 6 } & \multicolumn{1}{c}{$\mathbf{A}$} & \multicolumn{1}{c}{ B } & \multicolumn{1}{c}{ C } & \multicolumn{1}{c}{ D } \\
\hline Absolute Growth (g) & $0.32 \pm 0.04^{\mathrm{abc}}$ & $0.38 \pm 0.02^{\mathrm{d}}$ & $0.25 \pm 0.02^{\mathrm{a}}$ & $0.45 \pm 0.01^{\mathrm{d}}$ & $0.28 \pm 0.0007^{\mathrm{ab}}$ \\
SGR (\%) & $2.79 \pm 0.12^{\mathrm{ab}}$ & $2.97 \pm 0.11^{\mathrm{bc}}$ & $2.50 \pm 0.40^{\mathrm{a}}$ & $3.25 \pm 0.03^{\mathrm{d}}$ & $2.59 \pm 0.12^{\mathrm{ab}}$ \\
Feed Consumption Rate (\%) & $35.04 \pm 1.39^{\mathrm{bcd}}$ & $34.35 \pm 1.26^{\mathrm{bcd}}$ & $32.80 \pm 0.96^{\mathrm{bcd}}$ & $30.50 \pm 1.53^{\mathrm{d}}$ & $34.67 \pm 1.49^{\mathrm{bcd}}$ \\
EFU (\%) & $28.25 \pm 2.44^{\mathrm{a}}$ & $39.87 \pm 2.76^{\mathrm{bc}}$ & $31.61 \pm 10.2^{\mathrm{ab}}$ & $49.23 \pm 2.15^{\mathrm{d}}$ & $33.75 \pm 0.02^{\mathrm{ab}}$ \\
FCR & $2.43 \pm 0.26^{\mathrm{a}}$ & $2.40 \pm 0.38^{\mathrm{c}}$ & $2.30 \pm 0.79^{\mathrm{ab}}$ & $2.07 \pm 0.30^{\mathrm{d}}$ & $2.33 \pm 0.19^{\mathrm{abc}}$ \\
SR (\%) & $92.33 \pm 2.52^{\mathrm{a}}$ & $98.33 \pm 0.58^{\mathrm{bc}}$ & $98.67 \pm 1.15^{\mathrm{bcd}}$ & $99.67 \pm 0.58^{\mathrm{bcd}}$ & $98.33 \pm 1.53^{\mathrm{bcd}}$ \\
\hline
\end{tabular}

Note: A. Feed 50\% maggot flour and 50\% grated coconut, B. Feed 75\% maggot flour and 25\% grated coconut, C. Feed maggot flour $25 \%$ and grated coconut $75 \%$, D. Feed 100\% maggot flour, E. Feed 100\% grated coconut 
The highest absolute growth value, specific growth rate, feed consumption rate, and the highest efficiency of feed utilization was treatment D $(0.40 \% ; 0.85 \% ; 36.50 \%$ and $1.51 \%)$. The lowest value is Absolute growth, specific growth, feed consumption level and feed utilization efficiency in the treatment of Nereis sp. was treatment C $(0.25 \% ; 0.25 \% ; 32.80 \%$ and $0.29 \%)$.

The ANOVA results for the absolute weight value of Nereis sp. showed that feeding with maggot flour and grated coconut during the study had a significant effect $(P$ $<0.05)$ on absolute growth $\left(\mathrm{F}_{\text {count }}>\mathrm{F}_{\text {table }}\right)$. Based on the results of Duncan's multiple range test, the absolute weight value of Nereis sp. in treatment D was not significantly different from that in treatment $\mathrm{B}$ but was significantly different from those in treatments $\mathrm{C}, \mathrm{E}$, and $\mathrm{A}$.

The results of various analyses of the SGR values of Nereis sp. showed that feeding with maggot flour and grated coconut during the study had a significant effect $(P$ $<0.05)$ because of the value of $F_{\text {count }}>F_{\text {table }}$ of the SGR. Based on the results of Duncan's multiple range test, the SGR values of Nereis sp. in treatment D were very significantly different from those in treatments A, B, C, and E.

The results of the feed consumption rate analysis of Nereis sp. showed that feeding with maggot flour and grated coconut had a significant effect $(P<0.05)\left(\mathrm{F}_{\text {count }}>\right.$ $\left.F_{\text {table }}\right)$. Based on the results of Duncan's multiple range test, the SGR values of Nereis sp. were significantly different in treatment $\mathrm{D}$ than in treatments $\mathrm{A}, \mathrm{B}, \mathrm{C}$, and $\mathrm{E}$.

The results of the analysis of various values of the feeding efficiency of Nereis sp. showed that the feeding of maggot flour and grated coconut during the study had a significant effect $(P<0.05)\left(\mathrm{F}_{\text {count }}>\mathrm{F}_{\text {table }}\right)$. Based on the results of Duncan's multiple range test, the Nereis sp. feed efficiency utilization in treatment $\mathrm{D}$ was significantly different from those in treatments A, B, C, and E.

The ANOVA results for the FCR of Nereis sp. showed that feeding with maggot flour and grated coconut during the study had a significant effect $(P>0.05)\left(\mathrm{F}_{\text {count }}>\mathrm{F}_{\text {table }}\right)$. Based on the results of Duncan's multiple range test, the FCR values in treatment A were not significantly different from those in treatments $\mathrm{C}$ and $\mathrm{E}$ but were significantly different from those in treatment B and very significantly different from those in treatment D.

The results of the analysis of SR values of Nereis sp. showed that feeding with maggot flour and grated coconut had a significant effect $(P<0.05)$ because of the value of $\mathrm{F}_{\text {count }}>\mathrm{F}_{\text {table }} \mathrm{SR}$. Based on the results of Duncan's multiple range test, the SGR values of Nereis sp. in treatment D were not significantly different from those in treatments $\mathrm{C}$, $\mathrm{B}$, and $\mathrm{E}$, but were very significantly different from those in treatment $\mathrm{A}$.

The highest results of the analysis of the nutritional quality of protein and fat of Nereis sp. with the feeding of maggot flour $100 \%$ (D), namely $54.05 \%$ and $22.54 \%$, respectively. The lowest nutritional content of protein and fat was Nereis sp. with Maggot flour feed $25 \%$ and grated coconut 75 (C), which were $48.16 \%$ and $18.59 \%$, respectively. Nutritional value of sea worms (Nereis sp.) for 35 maintenance days is presented in Table 6 .

The highest amino acid profile was in Nereis sp. by feeding maggot flour $100 \%$ (D) with the highest methionine of $55.46 \mathrm{ppm}$. The lowest amino acid profile was in Nereis sp. with Maggot flour $25 \%$ feed and grated coconut $75(\mathrm{C})$ with tryptophan as much as $3.92 \mathrm{ppm}$. The results of the analysis of the total amino acid profile of the results of the analysis of amino acids sea worms (Nereis sp.) For 35 Maintenance Days are presented in Table 7.

The highest fatty acid profile was in Nereis sp. by feeding maggot flour $100 \%$ (D) with the highest EPA, $10.98 \%$. The lowest fatty acids profile was in Nereis sp. with Maggot flour feed $25 \%$ and grated coconut 75 (C) with EPA essential fatty acids as much as $3.88 \%$. The results of the analysis of the fatty acids of sea worms (Nereis sp.) for 35 maintenance days are presented in Table 8.

\section{Discussion}

Factors The factors that determine the success of aquaculture are feed type and quality (Gamis et al. 2016). Based on the results of previous studies, maggot flour and grated coconut have a very significant effect $(P<0.01)$ on the feed utilization efficiency, feed consumption rate, FCR, and SR; and a significant effect $(P<0.05)$ on the absolute growth and SGRs.

Regarding the absolute growth and SGRs of Nereis sp., the treatment with $100 \%$ maggot flour (D) produced the highest values, at $0.45 \pm 0.01 \mathrm{~g}$ and $3.25 \%$, respectively. The treatment with $25 \%$ maggot flour and $75 \%$ grated coconut (C) produced the lowest values, with an absolute growth of $0.25 \mathrm{~g}$ and specific growth rate of $2.5 \%$. These results are because the $100 \%$ maggot flour feed had the most appropriate nutritional content for the growth of sea worms. Feeds that contain animal proteins can be efficiently utilized and are more easily digested by sea worms. (Rasidi and Patria 2012). The high amount of fat in maggot flour is used both as an energy source and for growth. Maggot flour contains $40-50 \%$ protein and $30 \%$ fat, as well as amino acids such as cysteine, histidine, tryptophan, and tyrosine (Herawati et al. 2020).

Table 6. Nutritional value of sea worms (Nereis sp.) for 35 maintenance days

\begin{tabular}{|c|c|c|c|c|c|c|}
\hline \multirow{2}{*}{ Proximate } & \multirow{2}{*}{ Nereis sp. before treatment $(\%)$} & \multicolumn{5}{|c|}{ Nereis sp. after treatments (\%) } \\
\hline & & $\mathbf{A}$ & B & $\mathrm{C}$ & D & $\mathbf{E}$ \\
\hline Protein & $33.19 \pm 004$ & $50.65 \pm 0.03$ & $51.12 \pm 0.03$ & $48.16 \pm 0.06$ & $54.05 \pm 0.05$ & $49.77 \pm 0.08$ \\
\hline Fat & $19.98 \pm 0.03$ & $21.04 \pm 0.09$ & $22.22 \pm 0.02$ & $18.59 \pm 0.04$ & $22.54 \pm 0.02$ & $20.84 \pm 0.03$ \\
\hline Crude fiber & $15.89 \pm 0.02$ & $14.25 \pm 0.07$ & $10.92 \pm 0.07$ & $15.82 \pm 0.02$ & $10.39 \pm 0.05$ & $16.25 \pm 0.02$ \\
\hline Ash & $15.57 \pm 0.04$ & $7.18 \pm 0.09$ & $8.61 \pm 0.01$ & $8.83 \pm 0.08$ & $6.99 \pm 0.02$ & $8.18 \pm 0.01$ \\
\hline Carbohydrate & $15.37 \pm 0.01$ & $6.88 \pm 0.01$ & $6.83 \pm 0.02$ & $8.6 \pm 0.01$ & $6.03 \pm 0.01$ & $10.61 \pm 0.02$ \\
\hline
\end{tabular}

Note: A. Feed 50\% maggot flour and 50\% grated coconut, B. Feed 75\% maggot flour and 25\% grated coconut, C. Feed maggot flour $25 \%$ and grated coconut $75 \%$, D. Feed $100 \%$ maggot flour, E. Feed $100 \%$ grated coconut 
Table 7. Results of amino acid analysis of sea worms (Nereis sp.) for 35 maintenance days

\begin{tabular}{|c|c|c|c|c|c|c|}
\hline Amino Acid (ppm) & $\begin{array}{l}\text { Nereis sp } \\
\text { before treatment }\end{array}$ & $\mathbf{A}$ & $\mathbf{B}$ & $\mathbf{C}$ & D & $\mathbf{E}$ \\
\hline L Histidine & $9.96 \pm 0.04$ & $13.96 \pm 0.04$ & $16.28 \pm 0.02$ & $13.32 \pm 0.08$ & $20.07 \pm 0.04$ & $16.07 \pm 0.04$ \\
\hline L-Threonine & $12.30 \pm 0.03$ & $20.30 \pm 0.03$ & $26.75 \pm 0.04$ & $19.30 \pm 0.05$ & $27.48 \pm 0.06$ & $24.48 \pm 0.04$ \\
\hline L-Proline & $10.79 \pm 0.01$ & $20.79 \pm 0.01$ & $25.38 \pm 0.02$ & $20.59 \pm 0.03$ & $28.49 \pm 0.04$ & $24.49 \pm 0.03$ \\
\hline L-Tyrosine & $8.63 \pm 0.03$ & $20.63 \pm 0.03$ & $25.20 \pm 0.03$ & $19.23 \pm 0.02$ & $27.79 \pm 0.03$ & $23.76 \pm 0.05$ \\
\hline L-Leucine & $12.93 \pm 0.01$ & $32.93 \pm 0.01$ & $34.47 \pm 0.02$ & $30.93 \pm 0.05$ & $36.12 \pm 0.02$ & $36.12 \pm 0.03$ \\
\hline L-Aspartate & $14.04 \pm 0.04$ & $31.04 \pm 0.04$ & $29.25 \pm 0.02$ & $30.04 \pm 0.06$ & $44.68 \pm 0.03$ & $34.68 \pm 0.01$ \\
\hline L-Lysine & $7.99 \pm 0.06$ & $22.99 \pm 0.06$ & $19.19 \pm 0.03$ & $20.99 \pm 0.03$ & $24.30 \pm 0.02$ & $24.30 \pm 0.01$ \\
\hline Glycine & $16.99 \pm 0.01$ & $36.99 \pm 0.01$ & $41.50 \pm 0.04$ & $34.99 \pm 0.02$ & $48.61 \pm 0.03$ & $44.61 \pm 0.03$ \\
\hline L-Arginine & $6.41 \pm 0.03$ & $9.41 \pm 0.03$ & $7.749 \pm 0.03$ & $7.41 \pm 0.03$ & $9.71 \pm 0.01$ & $9.71 \pm 0.03$ \\
\hline L-Alanine & $25.49 \pm 0.03$ & $36.49 \pm 0.03$ & $34.90 \pm 0.04$ & $30.49 \pm 0.09$ & $40.88 \pm 0.03$ & $38.81 \pm 0.01$ \\
\hline L-Valin & $11.64 \pm 0.03$ & $21.65 \pm 0.03$ & $23.34 \pm 0.03$ & $19.65 \pm 0.06$ & $28.37 \pm 0.01$ & $23.37 \pm 0.01$ \\
\hline L-Isoleucine & $14.81 \pm 0.02$ & $19.81 \pm 0.02$ & $21.18 \pm 0.05$ & $15.81 \pm 0.01$ & $26.34 \pm 0.01$ & $21.34 \pm 0.02$ \\
\hline L-Phenylalanine & $16.33 \pm 0.04$ & $26.33 \pm 0.04$ & $29.46 \pm 0.04$ & $22.93 \pm 0.04$ & $35.15 \pm 0.05$ & $30.15 \pm 0.05$ \\
\hline L-Glutamic Acid & $26.15 \pm 0.04$ & $56.15 \pm 0.04$ & $52.78 \pm 0.04$ & $52.75 \pm 0.04$ & $69.14 \pm 0.04$ & $64.14 \pm 0.04$ \\
\hline L-Serin & $11.18 \pm 0.01$ & $21.18 \pm 0.01$ & $23.21 \pm 0.02$ & $18.98 \pm 0.01$ & $28.53 \pm 0.04$ & $24.53 \pm 0.03$ \\
\hline L-Tryptophan & $4.72 \pm 0.04$ & $4.72 \pm 0.04$ & $5.53 \pm 0.04$ & $3.92 \pm 0.04$ & $8.98 \pm 0.06$ & $4.98 \pm 0.04$ \\
\hline L-Methionine & $18.26 \pm 0.03$ & $38.26 \pm 0.03$ & $49.56 \pm 0.02$ & $32.26 \pm 0.03$ & $55.46 \pm 0.04$ & $40.37 \pm 0.03$ \\
\hline L-cystine & $12.34 \pm 0.04$ & $16.34 \pm 0.04$ & $15.62 \pm 0.04$ & $15.32 \pm 0.04$ & $21.60 \pm 0.04$ & $18.60 \pm 0.04$ \\
\hline
\end{tabular}

Note: A. Feed 50\% maggot flour and 50\% grated coconut, B. Feed 75\% maggot flour and 25\% grated coconut, C. Feed maggot flour $25 \%$ and grated coconut $75 \%$, D. Feed $100 \%$ maggot flour, E. Feed $100 \%$ grated coconut

Table 8. Results of analysis of fatty acids in sea worms (Nereis sp.) for 35 maintenance days

\begin{tabular}{|c|c|c|c|c|c|c|}
\hline Fatty acids (\%) & $\begin{array}{c}\text { Nereis sp } \\
\text { before treatment }\end{array}$ & $\mathbf{A}$ & B & $\mathbf{C}$ & D & $\mathbf{E}$ \\
\hline C 6: 0 & $0.12 \pm 0.05$ & $0.32 \pm 0.05$ & $0.37 \pm 0.01$ & $0.37 \pm 0.01$ & $0.47 \pm 0.09$ & $0.30 \pm 0.05$ \\
\hline C 8: 0 & $0.25 \pm 0.01$ & $0.35 \pm 0.01$ & $0.52 \pm 0.08$ & $0.79 \pm 0.01$ & $1.59 \pm 0.01$ & $0.75 \pm 0.01$ \\
\hline C 10: 0 & $0.17 \pm 0.03$ & $0.17 \pm 0.03$ & $0.19 \pm 0.01$ & $0.18 \pm 0.01$ & $1.36 \pm 0.04$ & $0.27 \pm 0.03$ \\
\hline C 11: 0 & $0.29 \pm 0.04$ & $0.29 \pm 0.04$ & $0.33 \pm 0.01$ & $0.28 \pm 0.01$ & $0.38 \pm 0.02$ & $0.31 \pm 0.04$ \\
\hline C12: 0 & $2.10 \pm 0.01$ & $3.19 \pm 0.01$ & $3.79 \pm 0.02$ & $2.01 \pm 0.04$ & $4.45 \pm 0.01$ & $2.79 \pm 0.01$ \\
\hline C 13: 0 & $0.75 \pm 0.03$ & $0.75 \pm 0.03$ & $0.12 \pm 0.01$ & $0.12 \pm 0.02$ & $2.42 \pm 0.04$ & $0.95 \pm 0.03$ \\
\hline C 14: 0 & $1.57 \pm 0.03$ & $1.57 \pm 0.03$ & $1.98 \pm 0.01$ & $1.88 \pm 0.02$ & $2.68 \pm 0.04$ & $1.33 \pm 0.03$ \\
\hline C $14: 1$ & $0.77 \pm 0.01$ & $0.77 \pm 0.01$ & $0.27 \pm 0.01$ & $0.17 \pm 0.01$ & $1.79 \pm 0.01$ & $0.89 \pm 0.01$ \\
\hline C 15: 0 & $0.51 \pm 0.03$ & $0.51 \pm 0.03$ & $0.63 \pm 0.03$ & $0.49 \pm 0.05$ & $0.98 \pm 0.03$ & $0.51 \pm 0.03$ \\
\hline C 16: 0 & $3.79 \pm 0.01$ & $3.79 \pm 0.01$ & $4.53 \pm 0.03$ & $3.63 \pm 0.04$ & $5.67 \pm 0.03$ & $2.89 \pm 0.01$ \\
\hline C $16: 1$ & $0.15 \pm 0.05$ & $0.37 \pm 0.05$ & $0.38 \pm 0.01$ & $0.39 \pm 0.04$ & $0.65 \pm 0.03$ & $0.17 \pm 0.05$ \\
\hline C 17: 0 & $0.13 \pm 0.04$ & $1.13 \pm 0.04$ & $0.57 \pm 0.04$ & $0.12 \pm 0.01$ & $3.52 \pm 0.04$ & $0.83 \pm 0.04$ \\
\hline C 18: 0 & $0.02 \pm 0.04$ & $1.67 \pm 0.04$ & $1.86 \pm 0.01$ & $0.99 \pm 0.01$ & $0.93 \pm 0.02$ & $0.67 \pm 0.04$ \\
\hline C 18: 1 & $0.55 \pm 0.04$ & $1.58 \pm 0.04$ & $2.58 \pm 0.04$ & $1.88 \pm 0.01$ & $2.98 \pm 0.03$ & $0.98 \pm 0.04$ \\
\hline C 18: 2 & $1.01 \pm 0.01$ & $1.18 \pm 0.01$ & $2.43 \pm 0.04$ & $1.13 \pm 0.03$ & $4.53 \pm 0.05$ & $1.35 \pm 0.01$ \\
\hline C 18: 3 & $0.04 \pm 0.03$ & $0.45 \pm 0.03$ & $4.37 \pm 0.02$ & $1.35 \pm 0.03$ & $6.55 \pm 0.04$ & $1.45 \pm 0.03$ \\
\hline C 20: 0 & $0.16 \pm 0.05$ & $0.39 \pm 0.05$ & $0.48 \pm 0.04$ & $0.37 \pm 0.02$ & $0.44 \pm 0.06$ & $0.19 \pm 0.05$ \\
\hline C 20: 1 & $0.12 \pm 0.04$ & $0.67 \pm 0.04$ & $0.58 \pm 0.03$ & $0.55 \pm 0.01$ & $0.96 \pm 0.04$ & $0.47 \pm 0.04$ \\
\hline C 20: 2 & $0.34 \pm 0.02$ & $0.79 \pm 0.02$ & $0.98 \pm 0.02$ & $0.98 \pm 0.03$ & $1.78 \pm 0.04$ & $0.69 \pm 0.02$ \\
\hline C 20: 4 & $0.15 \pm 0.04$ & $0.55 \pm 0.04$ & $0.64 \pm 0.05$ & $0.69 \pm 0.01$ & $0.98 \pm 0.04$ & $0.55 \pm 0.04$ \\
\hline EPA & $2.04 \pm 0.05$ & $5.09 \pm 0.05$ & $7.68 \pm 0.02$ & $3.88 \pm 0.01$ & $10.98 \pm 0.01$ & $6.09 \pm 0.05$ \\
\hline DHA & $1.63 \pm 0.02$ & $3.68 \pm 0.02$ & $5.58 \pm 0.03$ & $2.35 \pm 0.03$ & $7.36 \pm 0.03$ & $4.68 \pm 0.02$ \\
\hline
\end{tabular}

Note: A. Feed 50\% maggot flour and 50\% grated coconut, B. Feed 75\% maggot flour and 25\% grated coconut, C. Feed maggot flour $25 \%$ and grated coconut $75 \%$, D. Feed $100 \%$ maggot flour, E. Feed $100 \%$ grated coconut

In comparison, the proximate protein analysis of grated coconut found that it contained $14.31 \%$ protein, $6 \%$ fat, $8.4 \%$ fiber, $0.84 \%$ ash, and $57.38 \%$ water (Gamis et al. 2016). This balance of dietary fat and protein increases the growth of sea worms (Rasidi 2012). According to Gamis et al. (2016), one of the factors that determine the success of Nereis sp. aquaculture is the quality of the feed provided.

The use of $100 \%$ maggot flour feed produced the highest values, with an absolute growth of $0.45 \mathrm{~g}$ and a specific growth rate of $3.25 \%$ within the maintenance period of 35 days. The results of this study were better than those of the study conducted by Gamis et al. (2016), in which the absolute growth value of Nereis sp. fed grated coconut for 60 days was $0.42 \mathrm{~g}$; and lower than those of the study by Rasidi and Patria (2012), in which the highest absolute weight was $1.01 \mathrm{~g}$ with a treatment in the form of chicken intestine flour feed for 50 days. The growth rate in this study was higher than that reported by Gamis et al. 
(2016), in which the growth rate of sea worms fed $100 \%$ grated coconut for 60 days was $0.131 \%$; and Rasidi and Patria (2012), in which the growth rate of sea worms fed intestinal flour for 50 days was $1.76 \%$.

Maintenance of sea worms for 35 days with $100 \%$ maggot flour (D) showed the lowest feed consumption rate $(30.50 \%)$, which was inversely proportional to the absolute growth value and growth rate. This indicated that $100 \%$ maggot flour can be easily digested and has the nutrient content required by Nereis sp. to reduce feed costs, as well as high energy owing to its high protein and fat contents. The amount of feed given in relation to the FCR did not have a significant effect $(P>0.05)$ on the growth of sea worms; the lowest FCR in Nereis sp. was found to occur with $100 \%$ maggot flour feed (2.07). The lower the FCR, the higher the EFU. The FCR is the ratio between the amount of food given and weight gained; the lower the FCR value, the more efficient the animal increases its body weight. The FCR values in this study were higher than those found in Rasidi and Patria (2012), with an FCR of 0.65-1.63, and Gamis et al. (2016), with an FCR of 1.723.27 .

The highest feed efficiency in Nereis sp. was found in the $100 \%$ maggot flour treatment (D; 49.23\%) and the lowest was found in the 50\% maggot flour and 50\% grated coconut treatment $(\mathrm{A} ; 28.25 \%)$. From the results of the ANOVA, the EPP value had a significant effect $(P<0.01)$. This is because the maggot flour is absorbed by the sea worm's body effectively and efficiently, and can therefore be $100 \%$ utilized for growth. The feed efficiency is influenced by the nutrition source and the amount of each nutrition source in the feed (Herawati et al. 2020). According to Rasidi and Patria (2012), feed efficiency can affect growth.

The results of the proximate analysis are shown in Table 6. The results of the study showed that there were differences in each treatment. Nereis sp. fed $100 \%$ maggot flour (D) had the highest protein and fat contents, at $54.05 \%$ and $22.54 \%$, corresponding to $20.86 \%$ and $2.56 \%$ increases, respectively. The lowest nutrient contents were found in the $25 \%$ maggot flour and $75 \%$ grated coconut treatment (C), with $48.16 \%$ protein and $18.59 \%$ fat. The results of this study are reinforced by the statement of Rasidi and Patria (2012) that the growth rate shows the quality of feed provided; sea worms more easily digest nutrients from animal protein-sourced feed. Sources of fat in feed can also be used as an energy source and used for growth. Nereis sp. is the best live feed for shrimp; its high fatty acid content is ideal for ovarian growth and development. The fat content required by shrimp is $10 \%$ (Nguyen 2011). Fat is an important nutrient in the development of shrimp ovaries (Tocher 2015).

The amino acid profile results (Table 3) showed that treatment D gave the highest amino acid content, at 55.46 ppm up from $37.2 \mathrm{ppm}$, and increase of $18.26 \%$. The lowest amino acid content was found in C (32.26 ppm). The function of the essential amino acid methionine is to improve the balance and use of other amino acids to increase growth; it is essential for protein synthesis and other physiological functions. Methionine and cysteine are the primary sources of amino acid sulfate for animals; however, cysteine is not essential because it can be synthesized from methionine (Bhagavan, 1992). The body needs methionine for the formation of nucleic acids and synthesis of tissues and proteins. In addition, it forms other amino acids (cysteine) and vitamins (choline). Methionine works with vitamin B12 and folic acid to help the body to regulate excessive protein in a high-protein diet. The methionine requirement for fish feed is $2.30 \%$.

The synthesis of tissue proteins is mostly determined by the completeness and level of amino acids that enter or are transported into tissue cells. The synthetic process that takes place in the ribosome is very dependent on the presence of amino acids picked up by DNA and translated into the tissue (Rolland et al. 2015). The efficiency and magnitude of protein synthesis in tissue cells are greatly influenced by the completeness and balance of amino acids circulating and being translated into the tissue. Methionine is needed by fish to initiate protein synthesis and can affect muscle growth (Belghit 2014). It has been proven that the addition of methionine to the feed increases the growth and immune response (Yuan et al. 2011; Kuang et al. 2012; Boonyoung et al. 2013; Ma et al. 2013; Rolland et al. 2015). Methionine deficiency can cause decreased growth and survival in turbot (Psetta maxima) (Ma et al. 2013) and cobia (Rachycentron canadum) and cause cataracts in rainbow trout [Oncorhynchus mykiss (Walbaum)] (Boonyoung et al. 2013).

The highest total fatty acid profile was found in treatment D (10.98\%), and the lowest was found in treatment C $(3.88 \%)$ (Table 4$)$. Monounsaturated fatty acids and polyunsaturated fatty acids, including omega-3 fatty acids (EPA and DHA), play a role in reducing triacylglycerol levels and increasing the excretion process. They also increase the fluidity of cell membranes, forming eicosanoids that reduce platelets, and play an essential role in brain and retinal development. Fatty acids also play an essential role in the maturation process of the parent gonad to produce high-quality eggs; they are important factors that must be considered when providing shrimp feed during the gonad ripening process.

The SRs of Nereis sp. during 35 days of feeding with grated coconut and maggot flour was significantly high (94.00-99.67\%), with the highest being found in those fed $100 \%$ maggot flour and the lowest in those fed $50 \%$ maggot flour and $50 \%$ grated coconut (A). The results of this study were higher than those of Rasidi and Patria (2012), in which the SRs of Nereis sp. fed chicken intestine flour, blood meal, and shrimp head flour were 80.5692.22\%; and those of Gamis et al. (2016), in which the SR of Nereis sp. fed with $100 \%$ grated coconut was $96.3 \%$. The high SRs in this study shows that the quality and quantity of feed provided is sufficient to meet basic needs and can even increase growth. This is because the feed provided can be digested effectively and can support marine worm survival. The survival of sea worms can also be influenced by the cultivation media (Rasidi and Patria 2012).

The results of this study showed that the best treatment to support the cultivation of Nereis sp. was treatment D 
(100\% maggot meal). This was because $100 \%$ maggot flour has the most appropriate nutrient content for sea worms. According to Costa et al. (2000) and Rasidi and Patria (2012), a single feed is capable of supporting Nereis sp. survival. Maggot flour is a source of animal protein (Herawati et al. 2019); one alternative that can be used as feed in aquaculture is animal protein-containing feed (Rasidi and Patria 2012).

In conclusion, $100 \%$ maggot flour showed the highest absolute growth value, SGR, feed efficiency, and SR $(0.45 \mathrm{~g}, 3.25 \%, 49.23 \%$, and $99.67 \%)$, while the total feed consumption ranged from $30.50 \%$ to $34.67 \%$, and the FCR value ranged from $2.07-2.43 \%$. The nutrient contents of Nereis sp. in treatment D were $54.05 \%$ protein, $22.54 \%$ fatty acids, $55.46 \mathrm{ppm}$ methionine, and $10.98 \%$ EPA.

\section{ACKNOWLEDGEMENTS}

This work was funded by RPP (Research on the Development and Application) of funding sources other than the Diponegoro University State Budget (Non-APBN) for the 2020 budget year Number 233 85/UN7.6.1/pp/2020.

\section{REFERENCES}

Asnawi, Yusnaini, Idris M. 2018. Pengaruh Substrat yang Berbeda Terhadap Pertumbuhan Biomassa Cacing Laut (Nereis sp.). Media Akuatika 3 (2): 670- 679. [Indonesian]

Azir A, Harris H, Haris RBK. 2017. Production and nutritional content of maggots (Chrysomya Megacephala) using different culture media composition. Jurnal Ilmu-ilmu Perikanan dan Budidaya Perairan 12 (1): 34-40.

Belghit IC, Guerden SS, Dias I, Surget K, Kaushik A, Panserat S, Seiliez S I. 2014. Dietary methionine availability affects the main factor involved in muscle-protein turnover in rainbow trout (Oncorhynchus mykiss). Br J Nutr 112: 493-503.

Bhagavan NV. 1992. Medical Biochemistry. Jones and Barlett Publisher, India.

Boonyoung S, Haga Y, Satoh S. 2013. Preliminary study on the effects of methionine hydroxy analog and taurine supplementation in a soy protein concentrate based diet on the biological performance and amino acid composition of rainbow trout [Oncorhynchus mykiss (Walbaum)]. Aquacult Res 44: 1339-1347.

Gamis, Yusnaini, Sarita AH. 2016. Effect of feeding on sea worms growth (Nereis sp.). Media Akuatika 1 (4): 252-260.

Hadiyanto. 2013. Economic value of sea worms (Annelida: Polychaeta) Oseana 37 (3): 23-31.

Hartanti NU, Suyono. 2015. Different salinity and flake of mangrove leaf litter affect growth (Dendronereis pinnaticiris). Oseatek 9 (1): 45-55.
Herawati VE, Pinandoyo, Darmanto YS, Hutabarat J. 2019. Growth performance and nutrient content of carp (Cyprinus Carpio) with the feeding of maggot meal substitution cultivated in different media. IOP Conf Ser Earth Environ Sci 246: 012003. DOI: 10.1088/17551315/246/1/012003.

Herawati VE, Pinandoyo, Windarto S, Hariyadi P, Hutabarat J, Darmanto YS, Rismaningsih N, Prayitno SB, Radjasa OK. 2020. Maggot meal (Hermetia illucens) substitution on fish meal to growth performance and nutrient content of milkfish (Chanos chanos). Hayati J Biosci 27 (2): 154-165.

Hermawan D, Saifullah, Herdiyana D. 2015. The effect of different substrate of culture of Nereis sp. Jurnal Perikanan dan Kelautan 5 (1): 41-47.

Kuang SY, Xiao WW, Feng L. 2012. Effects of graded levels of dietary methionine hydroxy analog on immune response and antioxidant status of immune organs in juvenile Jian carp (Cyprinus carpio). Fish Shellfish Immunol 32: 629-636.

Ma R, Hou H, Mai K, Bharadwaj A S, Cao H, Ji F, Zhang W. 2013. Comparative study on the effects of L-methionine or 2-hydroxy-4(methylthio) butanoic acid as dietary methionine source on growth performance and antioxidative responses of turbot (Psetta maxima). Aquaculture 412-413: 136-143.

Mouneyrac C, Ettajani H, Triquet C. 2010. Influence of anthropogenic stress on fitness and behaviour of a key-species of estuarine ecosystems, the ragworm Nereis diversicolor. Environ Pollut 158: 121-128.

Munairi I. 2012. Study of density and distribution pattern of worms (Nereis sp.) in coastal waters, Kwanyar, Bangkalan. Jurnal Kelautan 5 (1): 47-51. [Indonesian]

Nguyen BT, Koshio S, Sayikama K, Ishikawa M, Yokoyama S, Kader MA. 2011. Effects of polychaete extracts on reproductive performance of kuruma shrimp, Marsupenaeus japonicus Bate. - Part II. Ovarian maturation and tissue lipid compositions. Aquaculture 334-337: 65-72

Rasidi, MP Patria. 2012. Growth and survival of Nereis sp. (Polychaeta, Annelida) given a different kind of feed. Jurnal Riset Akuakultur 7 (3): 447-464.

Rasidi. 2012. Dendronereis pinnaticirris seaworm hatchery: an initial effort to supply sea worm seeds for cultivation. Media Akuakultur. 7 (2): 88-91.

Rolland M, Dalsgaard J, Holm J, Gómez-Requeni P, Skov PV. 2015. Dietary methionine level affects growth performance and hepatic gene expression of GH-IGF system and protein turnover regulators in rainbow trout (Oncorhynchus mykiss) fed plant protein-based diets. Compar Biochem Physiol Part B 181: 33-41.

Tacon, A. E. J. 1993. Feed Ingredient for Warmwater Fish: Fish Meal and Other Processed Feedstuffs. FAO Fisheries Circular 856: 64. FAO< Rome.

Tocher DR. 2015. Omega-3 long-chain polyunsaturated fatty acids and aquaculture in perspective. Aquaculture 449: 94-107.

Wibowo ES, Palupi ES, Puspitasari IGAAR, Atang. 2019. Metabolism and nutritional content of Polychaeta Nereis sp. with maintenance salinity and different types of feed. Ilmu Kelautan Indon J Mar Sci 24 (3): 113-120.

Yuan YC, Gong SY, Yang HJ, Lin YC, Yu DH, Luo Z. 2011. Effects of supplementation of crystalline or coated lysine and/or methionine on growth performance and feed utilization of the Chinese sucker (Myxocyprinus asiaticus). Aquaculture 316: 31-36. 